\title{
An evaluation of the use of serum 7-alpha-hydroxycholestenone as a diagnostic test of bile acid malabsorption causing watery diarrhea
}

\author{
W Gordon Brydon FRCPath PhD ${ }^{1}$, Pearl Culbert BA RN ${ }^{1}$, Kathleen Kingstone MPhil ${ }^{1}$, Ann Jarvie HNC ${ }^{1}$, \\ Marietta lacucci MD PhD², Merel Tenhage ${ }^{3}$, Subrata Ghosh MD FRCP FRCPC FRCPE ${ }^{4}$
}

WG Brydon, P Culbert, K Kingstone, et al. An evaluation of the use of serum 7-alpha-hydroxycholestenone as a diagnostic test of bile acid malabsorption causing watery diarrhea. Can J Gastroenterol 2011;25(6):319-323.

BACKGROUND: Bile acid malabsorption (BAM) is a recognized cause of watery diarrhea, often diagnosed empirically based on clinical response to cholestyramine. The radionuclide selenium-labelled homocholic acid-taurine whole body retention test is expensive, labour intensive and of limited availability.

OBJECTIVE: To report on the clinical performance of serum 7-alphahydroxy-4-cholesten-3-one (7HCO) as a test of BAM in adult patients with unexplained diarrhea.

METHODS: Patients with unexplained diarrhea were investigated over a three-year period. Final diagnosis was determined based on medical history and investigations, serum levels of $7 \mathrm{HCO}$ and response to cholestyramine. ROC analysis was used to determine the ideal upper reference range cut-off value to optimize sensitivity/specificity for BAM. Time of blood specimen collection was recorded to investigate possible variation in results throughout the working day.

RESULTS: ROC analysis yielded a sensitivity/specificity of 90\%/77\% for type 1 BAM (ileal disease/resection) and $97 \% / 74 \%$ for type 2 BAM (idiopathic) using $30 \mathrm{ng} / \mathrm{mL}$ as the upper limit of normal for serum $7 \mathrm{HCO}$ when compared with all other patients. Of 813 patients, 196 tested positive. Serum 7HCO levels were significantly higher in blood specimens that were collected between 12:00 and 13:00 (median $24 \mathrm{ng} / \mathrm{mL}$ ) than in specimens collected between 09:00 and 10:00 (median $17 \mathrm{ng} / \mathrm{mL})(\mathrm{P}<0.05)$.

CONCLUSION: Serum 7HCO testing is a simple, sensitive, noninvasive, inexpensive alternative to other more commonly used tests for BAM. Time of specimen collection, however, resulted in small but significant result variations and, although unlikely to have much impact on test value, it should ideally be standardized.

Key Words: 7-alpha-hydroxy-4-cholesten-3-one; Bile acid malabsorption; Watery diarrhea

$\mathrm{B}$ le acid malabsorption (BAM) is a well recognized disorder resulting in watery diarrhea. It is often underdiagnosed because standardized tests are not readily available and are expensive. Empirical treatment is frequently used, but the outcome may be unpredictable in the absence of a precise diagnosis. Three types of BAM have been described: type 1 (ileal resection, disease or bypass of terminal ileum), type 2 (primary idiopathic) and type 3 (associated with cholecystectomy, diabetes mellitus, peptic ulcer surgery, celiac disease and chronic pancreatitis).

The most widely used investigation to diagnose BAM is the seleniumlabelled homocholic acid-taurine whole body retention (SeHCAT WBR) test. Serum 7-alpha-hydroxy-4-cholesten-3-one (7HCO) is the established test to determine hepatic bile acid synthesis/turnover and directly correlates with the activity of hepatic cholesterol

\section{Une évaluation de l'utilisation du 7-alpha- hydroxycholesténone sérique comme test diagnostique de la malabsorption des sels biliaires responsable de diarrhée aqueuse}

\begin{abstract}
HISTORIQUE : La malabsorption des sels biliaires (MSB) est une cause reconnue de diarrhée aqueuse, souvent diagnostiquée de manière empirique d'après la réponse clinique à la cholestyramine. Le test à l'acide taurohomocholique marqué au sélénium radioactif est coûteux et peu accessible, sans compter qu'il demande beaucoup de travail.

OBJECTIF : Rendre compte du rendement clinique du 7-alpha-hydroxy4-cholesten-3-one (7HCO) sérique comme test de la MSB chez les patients adultes ayant une diarrhée d'origine inexpliquée.

MÉTHODOLOGIE : Les patients ayant une diarrhée inexpliquée ont subi des examens pendant une période de trois ans. Le diagnostic définitif a été posé d'après les antécédents médicaux et les explorations, les taux sériques de $7 \mathrm{HCO}$ et la réponse à la cholestyramine. L'analyse de fonction d'efficacité du récepteur a permis de déterminer la valeur seuil supérieure idéale pour optimiser la sensibilité et la spécificité de la MSB. Les chercheurs ont enregistré le moment du prélèvement de sang pour explorer la variation possible des résultats tout au long de la journée de travail.

RÉSULTATS : L'analyse de fonction d'efficacité du récepteur a donné lieu à une sensibilité et une spécificité de $90 \%$ et $77 \%$ en cas de MSB de type 1 (maladie ou résection iléale) et de $97 \%$ et $74 \%$ en cas de MSB de type 2 (idiopathique), en établissant $30 \mathrm{ng} / \mathrm{mL}$ comme limite supérieure du $7 \mathrm{HCO}$ sérique normal par rapport à tous les autres patients. Sur les 813 patients, 196 ont obtenu des résultats positifs. Les taux de 7HCO sérique étaient considérablement plus élevés dans les prélèvements de sang obtenus entre $12 \mathrm{~h}$ et $13 \mathrm{~h}$ (médiane de $24 \mathrm{ng} / \mathrm{mL}$ ) que dans ceux prélevés entre $9 \mathrm{~h}$ et $10 \mathrm{~h}$ (médiane de $17 \mathrm{ng} / \mathrm{mL})(\mathrm{P}<0,05)$.

CONCLUSION : Le test de 7HCO sérique est une solution simple, sensible, non effractive et peu coûteuse par rapport aux tests utilisés plus couramment en cas de MSB. Cependant, l'heure du prélèvement a donné lieu à des variations petites mais significatives des résultats. Même s'il est peu probable que cette heure ait des répercussions marquées sur la valeur des tests, il serait préférable de la normaliser.
\end{abstract}

7-alpha-hydroxylase activity - a rate limiting enzyme in the conversion of cholesterol to bile acids (1). The relationship between serum levels of $7 \mathrm{HCO}$ and BAM was first highlighted by Axelson et al (2), and has since been further investigated and validated by Eusufzai et al (3), Brydon et al (4), Sauter et al (5) and Bajor et al (6) in comparisons with the SeHCAT WBR test.

The circadian rhythm of serum $7 \mathrm{HCO}$ was measured in detail by Galman et al (7) in a small number of subjects. The latter group showed serum $7 \mathrm{HCO}$ results in five normal subjects that were two- to three-fold higher at midday compared with 09:00, and that these values were not influenced by diet.

In the present study, the serum $7 \mathrm{HCO}$ test was re-evaluated for recovery, interference and precision in the context of clinical use in a

${ }^{1}$ Departments of Clinical Biochemistry and Gastroenterology, Western General Hospital, Edinburgh; ${ }^{2}$ Hammersmith Hospital, Imperial College London,

United Kingdom; ${ }^{3}$ Nova College, The Netherlands (Visiting student); ${ }^{4}$ Division of Gastroenterology, University of Calgary, Calgary, Alberta

Correspondence: Dr Subrata Ghosh, Department of Medicine, Foothills Medical Centre, North Tower, 1409-29th Street Northwest, Calgary,

Alberta T2N 2T9. Telephone 403-944-8222, fax 403-944-1095, e-mail ghosh@ucalgary.ca

Received for publication October 18, 2010. Accepted November 12, 2010 
TABLE 1

Serum recovery of 7-alpha-hydroxy-4-cholesten-3-one

\begin{tabular}{llc}
\hline Sera & $\mathbf{n}$ & Recovery, \% (mean [range]) \\
\hline Normal & 9 & $89(79-95)$ \\
Icteric & 3 & $86(81-91)$ \\
Lipemic & 3 & $87(81-97)$ \\
Hemolyzed & 3 & $89(85-93)$ \\
\hline
\end{tabular}

large number of patients. A commercial standard has now been used, and the use of potential internal standard (IS) described.

An evaluation of the use of the $7 \mathrm{HCO}$ test for diagnosis of BAM in a clinical setting is reported, including an analysis of optimum cut-off values and an assessment of the influence the time of the day of specimen collection has on results. We hope that these data will contribute to the optimization of the serum $7 \mathrm{HCO}$ assay as a clinical test of BAM in patients with unexplained diarrhea. As a clinical test, more widespread adoption of serum $7 \mathrm{HCO}$ analysis will aid in providing a routine diagnostic test for patients presenting with watery diarrhea.

\section{METHODS}

Serum levels of $7 \mathrm{HCO}$ were measured using high-performance liquid chromatography according to methods described previously (4), with minor differences. The volume of serum assayed was reduced from $1 \mathrm{~mL}$ to $0.5 \mathrm{~mL}$, and a potential IS - 4-cholesten-6-beta-ol-3-one (Steraloids, United Kingdom [UK]) - was assessed. Assay precision was assessed by repeat analysis of an individual spiked human serum sample in different test analysis runs, while recovery was assessed by spiking nine normal, three lipemic, three hemolyzed and three icteric samples with a known amount of 7HCO (Steraloids, UK). The method has now been standardized more accurately using material currently available from Steraloids UK, replacing the original standard, which was a gift of approximately $1 \mathrm{mg}$. Ten milligrams of $7 \mathrm{HCO}$ was dissolved in $25 \mathrm{~mL}$ of ethanol and used as the initial stock standard.

\section{Patients}

The serum $7 \mathrm{HCO}$ test was performed on 1846 patients in the southeast of Scotland over a three-year period. Final diagnoses were established in 813 patients who attended as outpatients at the Western General Hospital, Lothian University Hospitals NHS Trust, Edinburgh, Scotland. Patients from other hospitals and general practitioners were not followed-up and, therefore, a conclusive diagnosis was not established.

Patients were classified as having type 1, 2 or 3 BAM, or other, based on standard investigation results, medical evaluation and response to bile acid sequestrant therapy when believed to be clinically indicated. Patients were only included in the type 2 group if they responded favourably to bile acid sequestrant therapy.

In 1390 of 1846 patients, the exact time of day of specimen collection was recorded on the request form for the serum $7 \mathrm{HCO}$ assay. Results were plotted against time of day, and differences in median values were assessed using ANOVA (Kruskal-Wallis test). This analysis was repeated excluding values above $50 \mathrm{ng} / \mathrm{mL}$ to assess any shift in the median for values within and slightly above the reference range $(n=1103)$.

\section{Analytical aspects of the assay}

\section{RESULTS}

Assessment of 4-cholesten-6-beta-ol-3-one as a proposed IS: Several substances with a chemical structure somewhat similar to $7 \mathrm{HCO}$ were investigated as IS candidates for this procedure. Most were rejected on the basis of poor optical density at measured wavelength, inadequate recovery in the analytical procedure or unsuitable retention time on the chromatogram. However, 4-cholesten-6-beta-ol-3-one was investigated further. Five serum samples were spiked with 4-cholesten-6-beta-ol-3-one and taken through the full sample preparation. The same five samples were spiked near the end of the sample preparation in the elution tubes before evaporation. Nine samples were analyzed without IS. The IS was run without samples to assess percentage recovery.

The mean recovery of the proposed IS was $72 \%$ (range $70 \%$ to $75 \%$ ) when taken though the full procedure, and 99\% (range 98\% to $100 \%$ ) when added at the final stage before evaporation. The mean interference from other peaks coeluting with IS was $2.2 \%$ (range $1.8 \%$ to $3.6 \%$ ).

Because of poor recovery of IS when taken through the full procedure, and small amounts of interference from coeluting peaks, it was decided to exclude 4-cholesten-6-beta-ol-3-one as an IS for quantitation of results. However, the IS was included in the elution tubes before evaporation because it was a useful marker peak and assisted in identification of the test peak when it eluted closely with other peaks in the test chromatogram. 4-cholesten-6-beta-ol-3-one elutes at approximately $6.5 \mathrm{~min}$, approximately $2 \mathrm{~min}$ before the test $7 \mathrm{HCO}$ peak. 7-beta-OH-cholestenone is used as an IS in a subsequently described high-performance liquid chromatography method (8) that uses reversephase chromatography; however, this coeluted with $7 \mathrm{HCO}$ in the normal phase method as used in our procedure.

Recovery of 7HCO added to normal, icteric, lipemic and hemolyzed sera: Recovery of $7 \mathrm{HCO}$ from sera spiked with $7 \mathrm{HCO}$ was analyzed using normal, icteric, lipemic and hemolyzed sera. As shown in Table 1, recoveries under these different conditions were comparable.

Analytical precision: The coefficient of variation for quality control material (normal sera spiked with standard to give a result of approximately $70 \mathrm{ng} / \mathrm{mL}$ ) analyzed with each test batch of analyses was $7.5 \%$ $(\mathrm{n}=35)$.

\section{Analysis of patient results}

ROC analysis: The ROC curves are shown in Figures $1 \mathrm{~A}$ to $1 \mathrm{C}$. The sensitivity, specificity and likelihood ratios for type 1 and type 2 BAM, with $30 \mathrm{ng} / \mathrm{mL}$ selected as the optimal serum $7 \mathrm{HCO}$ cut-off value, are shown in Table 2. Clinically, distinguishing type 2 BAM from irritable bowel syndrome (IBS) is often difficult without a trial of cholestyramine. IBS patients with high levels of serum $7 \mathrm{HCO}$ did not respond to bile acid sequestrants. Figure 2 shows the distribution of serum $7 \mathrm{HCO}$ in patients diagnosed with IBS and patients diagnosed with idiopathic BAM.

Serum $7 \mathrm{HCO}$ in different groups of patients: As expected, serum levels of $7 \mathrm{HCO}$ were abnormal in the vast majority of patients with terminal ileal disease or terminal ileal resection (Table 3). Therefore, in this group, the serum $7 \mathrm{HCO}$ assay provides a diagnosis of BAM and leads to specific treatment. Similarly, the vast majority of patients with type 2 BAM had abnormal serum levels of $7 \mathrm{HCO}$. The median serum $7 \mathrm{HCO}$ concentration was highest in the ileal disease and idiopathic BAM groups (Table 4).

Others - alcoholic liver disease $(n=4)$, colonic polyps $(n=3)$, functional obstructive defecation and constipation $(n=3)$, Helicobater pylori infection (7), ileostomy $(n=1)$, laxative abuse $(n=4)$, microcytic colitis $(n=4)$, esophagitis $(n=2$,$) pelvic floor damage (n=5)$, solitary rectal ulcer $(n=1)$, nonulcer dyspepsia $(n=1)$, previous Whipple's resection for calcific pancreatitis $(n=1)$, nonulcer dyspepsia $(n=1)$, food allergy $(n=1)$, drug related $(n=14)$ and antibiotics $(n=3)$.

Influence of the time of specimen collection on serum 7HCO: Sera collected between 12:00 and 13:00 had significantly higher 7HCO levels than sera collected between 09:00 and 10:00 (Table 5).

\section{DISCUSSION}

The seven-day SeHCAT WBR test is currently the test of choice for the diagnosis and measurement of BAM in the UK and in many western countries. This test is designed to be exquisitely sensitive in that it measures the total bile acid retained in the body over a seven-day period during which the gall bladder may empty more than 30 times and the ileum will be challenged to reabsorb bile acids which are otherwise lost into feces. In 2003/2004, there were a total of 2396 tests performed for BAM in all other major centres in the UK - 1732 SeHCAT tests and $664{ }^{14} \mathrm{C}$ glycocholate tests (9). The SeHCAT WBR test was 


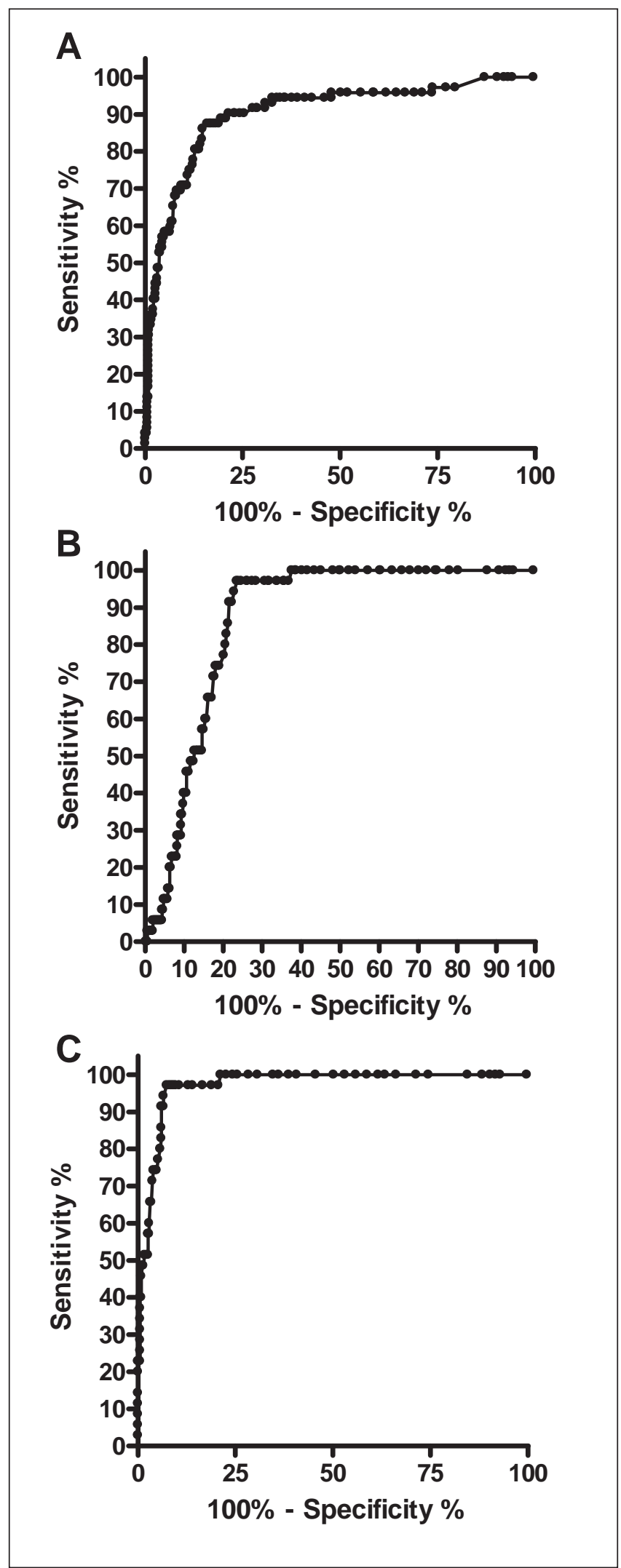

Figure 1) ROC curves. A Type 1 bile acid malabsorption syndrome (BAM) (all other patients as controls). Area under ROC curve $=0.90$; 95\% CI 0.86 to 0.94; P<0.0001. B Type 2 BAM (all other patients as controls). Area under ROC curve $=0.87 ; 95 \%$ CI 0.83 to 0.90 ; $P<0.0001$. C Type 2 BAM (all irritable bowel syndrome patients as controls). Area under ROC curve $=0.97 ; 95 \%$ CI 0.95 to 0.99; $P<0.0001$
TABLE 2

Serum 7-alpha-hydroxy-4-cholesten-3-one with $30 \mathrm{ng} / \mathrm{mL}$ cut-off: Sensitivity, specificity and likelihood ratios for bile acid malabsorption (BAM)

\begin{tabular}{lccc}
\hline & \multicolumn{2}{c}{$\%$} & Likelihood \\
\cline { 2 - 4 } BAM & Sensitivity & Specificity & ratio \\
\hline Type 1 (all other patients as controls) & 90 & 77 & 4.0 \\
Type 2 (all other patients as controls) & 97 & 74 & 3.7 \\
Type 2 (IBS patients as controls) & 97 & 91 & 10.6 \\
\hline
\end{tabular}

IBS Irritable bowel syndrome

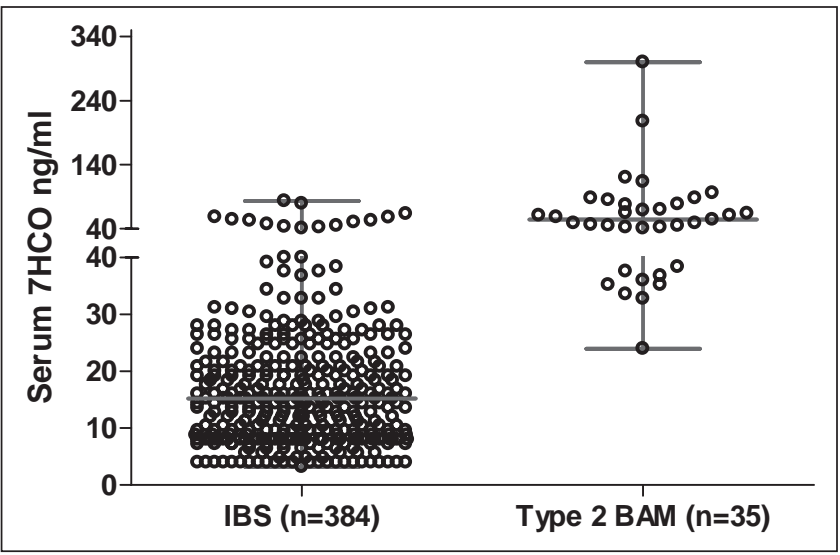

Figure 2) Serum 7-alpha-hydroxy-4-cholesten-3-one (7HCO) concentrations in patients with irritable bowel syndrome (IBS) and type 2 bile malabsorption (BAM). Data presented as median and range

available in our hospital and undertaken at the discretion of the physician. However, after the previous study (4), the majority of patients were investigated with serum $7 \mathrm{HCO}$ testing only.

Serum $7 \mathrm{HCO}$ is essentially a test of bile acid turnover, which has been shown in several studies to correlate inversely with the SeHCAT WBR test, with the most recent confirmation by Bajor et al (6). In the present study, the test was re-evaluated for methodological accuracy and shown to be highly sensitive (greater than 90\%) for the diagnosis of BAM types 1 and 2. A significant number of patients with IBS (9\% of total analyzed) had elevated results. This confirmed our earlier study (4) and has recently been examined extensively by Wedlake et al (10), who reviewed other literature with studies confirming that BAM was demonstrated in $10 \%$ to $32 \%$ of patients with diarrhea-predominant IBS by the SeHCAT WBR test. This may be a question of semantics; however, unlike type 2 BAM, IBS patients typically do not respond to bile acid sequestrants.

Serum $7 \mathrm{HCO}$ is less specific for ileal disease per se than SeHCAT WBR because it is also affected by bacterial colonization with bile salt deconjugation in the small bowel, to which the SeHCAT molecule is largely resistant. Overall, eight of 13 patients with small bowel colonization had raised serum levels of $7 \mathrm{HCO}$. In this respect, it is similar to the ${ }^{14} \mathrm{C}$ glycocholate breath test that is used both as a test for small bowel bacterial colonization and ileal disease.

Although figures for specificity are relatively low, the test is highly sensitive for type 2 BAM, with a specificity of $90 \%$ and a likelihood ratio of 10 when using the IBS group as control. Furthermore other conditions that predispose to BAM, such as ileal resection, postcholecystectomy diarrhea and diabetes, can quickly be identified from the primary pathology. The median serum $7 \mathrm{HCO}$ concentration for the type 2 BAM group was $58 \mathrm{ng} / \mathrm{mL}$, which was similar to that reported by Bajor et al (6) (median of $49 \mathrm{ng} / \mathrm{mL}$ in 12 patients).

Although time of day of specimen sampling influenced the results to some extent (median increase of $7 \mathrm{ng} / \mathrm{mL}$ between 09:00 and 13:00, reducing to $3 \mathrm{ng} / \mathrm{mL}$ when excluding values greater than $50 \mathrm{ng} / \mathrm{mL}$ ), in practice, this has had little effect in the diagnostic value of this test. Galman et al (7) showed increases in normal individuals of two- to 
TABLE 3

Patient diagnoses and number of patients with abnormal serum levels of 7-alpha-hydroxy-4-cholesten-3-one (cut-off value $=\mathbf{3 0} \mathrm{ng} / \mathrm{mL}$ )

\begin{tabular}{|c|c|c|}
\hline BAM & Pathology & Abnormal/total \\
\hline \multirow[t]{7}{*}{ Type 1} & Tertiary ileal resection & $27 / 28$ \\
\hline & Ileal Crohn's disease & $35 / 36$ \\
\hline & Ileal ulceration & $1 / 2$ \\
\hline & Ileal Crohn's stricture & $0 / 1$ \\
\hline & Radiation damage & $1 / 3$ \\
\hline & Short bowel syndrome & $2 / 2$ \\
\hline & Total, n/n (\%) & $66 / 72(92)$ \\
\hline Type 2 & Idiopathic primary BAM, n/n (\%) & $34 / 35(97)$ \\
\hline \multirow[t]{24}{*}{ Type 3} & Bacterial overgrowth & $8 / 13$ \\
\hline & Chronic pancreatitis & $2 / 11$ \\
\hline & Colonic Crohn's disease & $2 / 33$ \\
\hline & Celiac disease & $1 / 17$ \\
\hline & Colectomy & $3 / 4$ \\
\hline & Collagenous colitis & $1 / 6$ \\
\hline & Colorectal cancer & $2 / 8$ \\
\hline & Diabetes mellitus & $10 / 19$ \\
\hline & Diverticular disease & $5 / 35$ \\
\hline & FOD with overflow diarrhea & $4 / 17$ \\
\hline & Ileal conduit & $1 / 1$ \\
\hline & Ileal pouch anal anastomosis & $1 / 2$ \\
\hline & Gallstones & $2 / 7$ \\
\hline & IBS & $30 / 349$ \\
\hline & IBS postinfection & $6 / 35$ \\
\hline & Lactose malabsoprtion & $1 / 2$ \\
\hline & Postcholecystectomy & $8 / 16$ \\
\hline & Postgastrectomy & $1 / 2$ \\
\hline & Postvagotomy & $1 / 2$ \\
\hline & Salmonella infection & $1 / 1$ \\
\hline & Ulcerative colitis & $6 / 34$ \\
\hline & Others & $0 / 55$ \\
\hline & Total, n/n (\%) & $96 / 669$ (14) \\
\hline & Alcohol related & $10 / 37$ \\
\hline
\end{tabular}

Data presented as $n / n$ unless otherwise indicated. BAM Bile acid malabsorption; FOD Functional obstructive defecation; IBS Irritable bowel syndrome

TABLE 4

Serum 7-alpha-hydroxy-4-cholesten-3-one levels for major groups of bile acid malabsorption (BAM) patients

\begin{tabular}{lcc}
\hline BAM group & Median, $\mathbf{n g} / \mathbf{m L}$ & Range, $\mathbf{n g} / \mathbf{m L}$ \\
\hline lleal resection & 83 & $8-368$ \\
Ileal Crohn's disease & 90 & $16-344$ \\
Idiopathic & 54 & $24-300$ \\
Irritable bowel syndrome & 15 & $4-83$ \\
Postcholecystectomy & 30 & $11-310$ \\
Diabetes mellitus & 34 & $4-99$ \\
Bacterial colonization & 33 & $10-84$ \\
Alcohol related & 19 & $4-84$ \\
\hline
\end{tabular}

three-fold above basal morning levels within $4 \mathrm{~h}$. It may be that in patients with diarrhea such variation is, to some extent, mitigated. The same group also showed that diet had no effect on the results. Although our study patients were asked to arrive fasted for the test, in practice, this was unlikely to have been the case for patients arriving after midday (Figure 3).
TABLE 5

Serum 7-alpha-hydroxy-4-cholesten-3-one concentrations when the specimen was collected between 09:00 and 10:00, and between 12:00 and 13:00

\begin{tabular}{lccc}
\hline & \multicolumn{2}{c}{ Collection } & \multirow{2}{*}{$\mathbf{P}^{*}$} \\
\cline { 2 - 3 } & $\mathbf{0 9 : 0 0 - 1 0 : 0 0}$ & $\mathbf{1 2 : 0 0 - 1 3 : 0 0}$ & $<0.05$ \\
All patient results, ng/mL & $16.5(155)$ & $24.1(188)$ & $<0.02$ \\
Patient results, $<51 \mathrm{ng} / \mathrm{mL}$ & $13.3(126)$ & $16.5(146)$ & \\
\hline
\end{tabular}

Data presented as median (n). *Kruskal-Wallis test

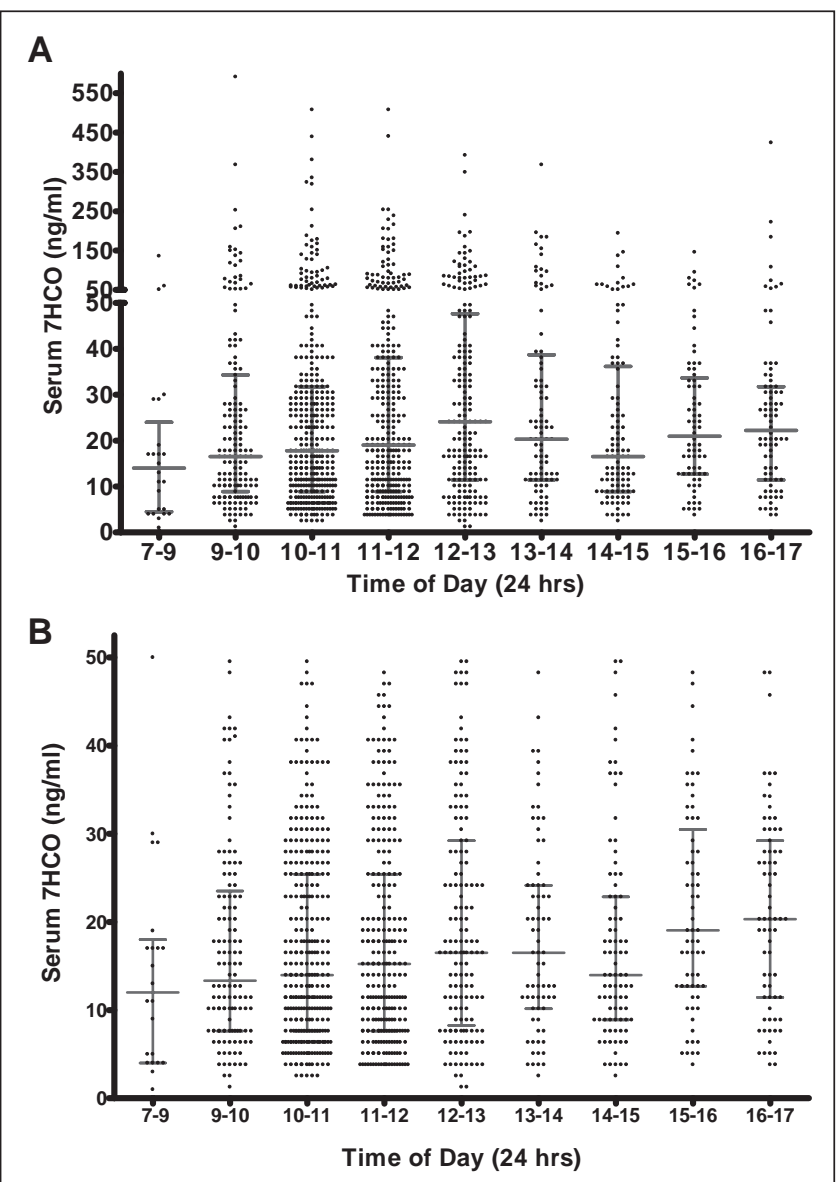

Figure 3) A Influence of the time of specimen collection on serum 7-alphahydroxy-4-cholesten-3-one (7HCO) levels in patients presenting with chronic diarrhea (median and interquartile range). B Influence of the time of specimen collection on serum 7HCO in patients presenting with chronic diarrhea for whom serum $7 \mathrm{HCO}$ levels were below $51 \mathrm{ng} / \mathrm{mL}$ (median and interquartile range)

\section{CONCLUSION}

Although the SeHCAT test has been shown to be a robust test of bile acid malabsorption, the expense, use of gamma radiation and the patient time involved would clearly preclude it as an automatic selection when choosing a test for BAM, when such a relatively simple, effective test as serum $7 \mathrm{HCO}$ is available. With the ever increasing use and availability of mass spectroscopy in diagnostic laboratories and the recent report by Camilleri et al (11), it is likely that the serum $7 \mathrm{HCO}$ test will become more widely available.

CONFLICTS OF INTEREST: The authors have no financial disclosures or conflicts of interest to declare. 


\section{REFERENCES}

1. Axelson A, Bjorkhem I, Reihner E, Einarsson K. The plasma level of 7 alpha-hydroxy-4-cholesten-3-one reflects the activity of hepatic cholesterol 7 alpha-hydroxylase in man. FEBS Lett 1991;284:216-8.

2. Axelson M, Aly A, Sjovall J. Levels of 7 alpha-hydroxy-4cholesten-3-one in plasma reflect rates of bile acid synthesis in man. FEBS Lett 1988;239:324-8.

3. Eusufzai S, Axelson M, Angelin B, Einarsson K. Serum 7 alphahydroxy-4-cholesten-3-one concentrations in the evaluation of bile acid malabsorption in patients with diarrhoea: Correlation to SeHCAT test. Gut 1993;34:698-701.

4. Brydon WG, Nyhlin H, Eastwood M, Merrick M. Serum 7 alphahydroxy-4-cholesten-3-one and selenohomocholyltaurine (SeHCAT) whole body retention in the assessment of bile acid induced diarrhoea. Eur J Gastroenterol Hepatol 1996;8:117-23.

5. Sauter G, Munzing W, Von Ritter C, Paumgartner G. Bile acid malabsorption as a cause of chronic diarrhoea: Diagnostic value of 7 alpha-hydroxy-4-cholesten-3-one in serum. Dig Dis Sci $1999 ; 44: 14-9$.
6. Bajor A, Kilander A, Fae A, et al. Normal or increased bile acid uptake in isolated mucosa from patients with bile acid malabsorption. Eur J Gastroenterol Hepatol 2006;18:397-403.

7. Galman C, Angelin B, Rudling M. Bile acid synthesis in humans has a rapid diurnal variation that is asynchronous with cholesterol synthesis. Gastroenterology 2005;129:1445-53.

8. Petterson L, Eriksson CG. Reversed-phase high performance liquid chromatographic determination of 7-alpha-hydroxy-4-cholesten-3-one in human serum. J Chromatog 1994;657:31-6.

9. Hart D, Wall BF. UK nuclear medicine survey 2003-2004. Nucl Med Commun 2005;26:937-46.

10. Wedlake L, A'Hern R, Russell D, Thomas K, Walters JR, Andreyev HJ. Systematic review: The prevalence of idiopathic bile acid malabsorption as diagnosed by SeHCAT scanning in patients with diarrhoea-predominant irritable bowel syndrome. Aliment Pharmacol Ther 2009;30:707-17.

11. Camilleri M, Nadeau A, Tremaine WJ, et al. Measurement of serum 7 alpha-hydroxy-cholesten-3-one, a surrogate test for bile acid malabsorption in health, ileal disease, and irritable bowel syndrome using liquid chromatography-tandem mass spectrometry. Neurogastroenterol Motil 2009;21:e734-43. 


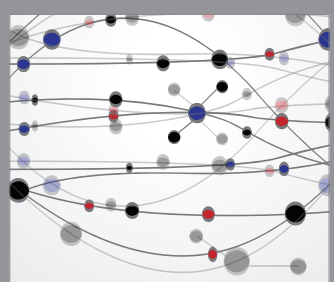

The Scientific World Journal
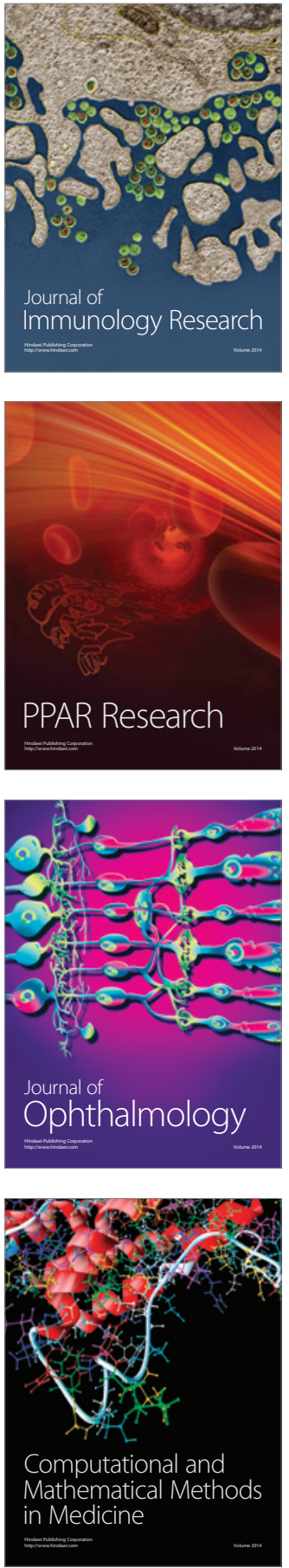

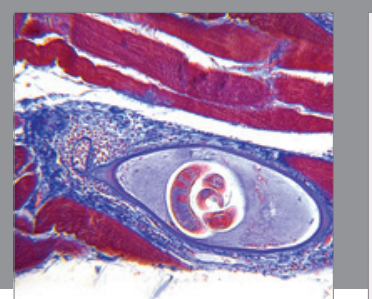

Gastroenterology Research and Practice

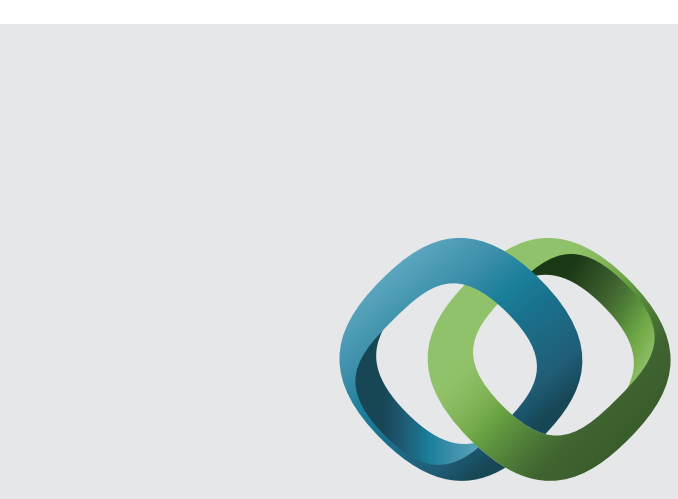

\section{Hindawi}

Submit your manuscripts at

http://www.hindawi.com
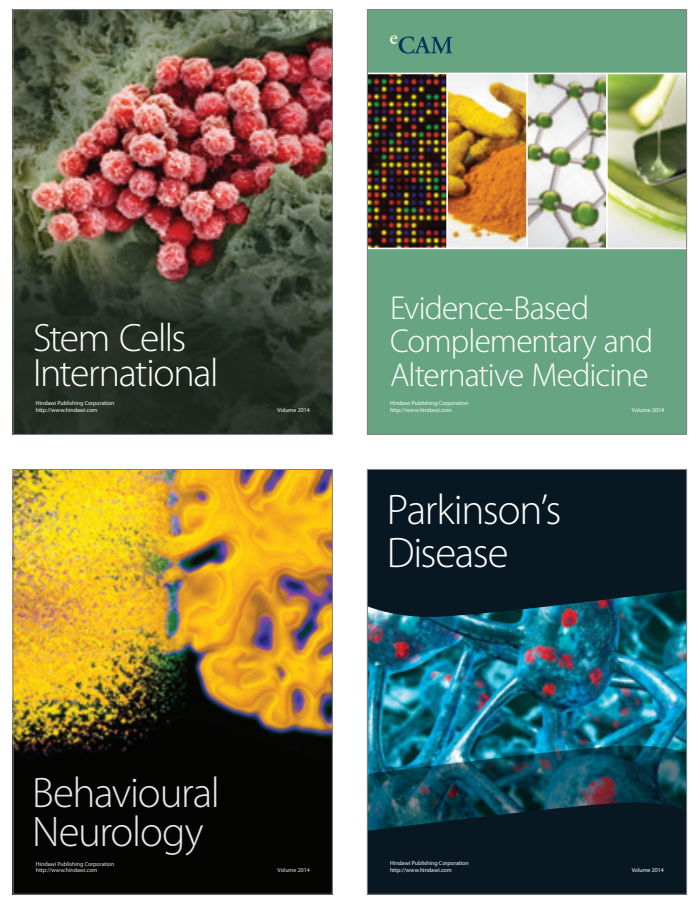
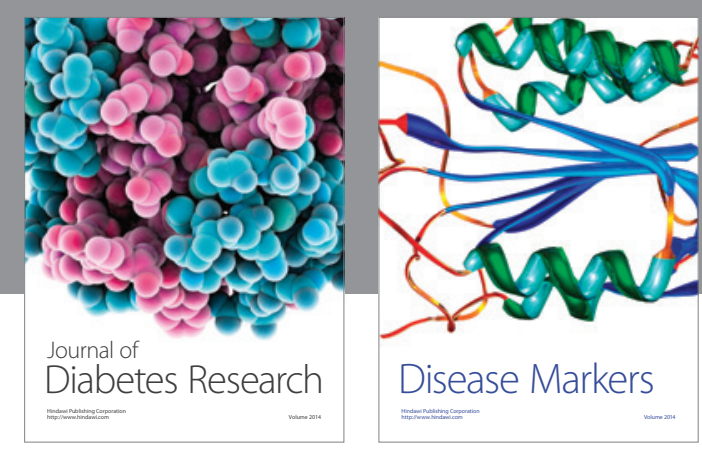

Disease Markers
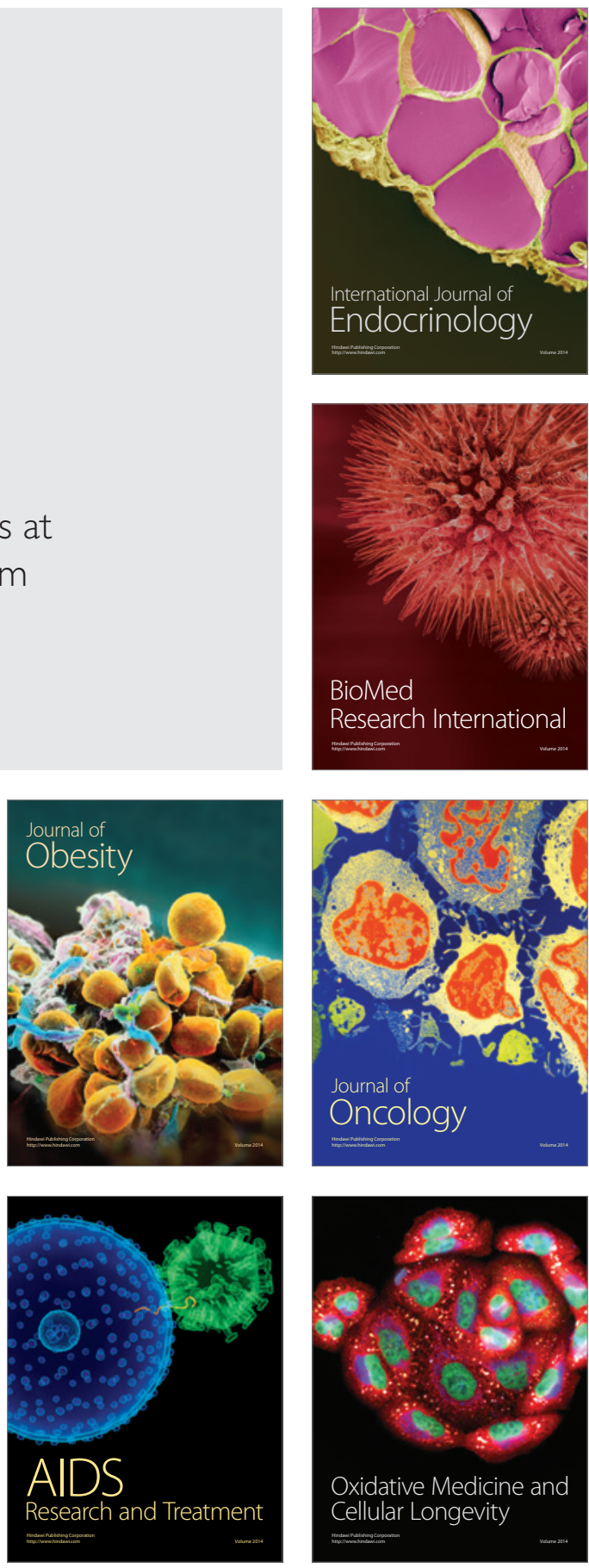